\title{
A MODEL OF SOCIALLY RESPONSIBLE ORGANIZATIONAL CULTURE
}

\author{
Cristina Ganescu PhD \\ “Constantin Brâncoveanu” University, Piteşti, Romania \\ Email: cristina_ganescu@yahoo.com \\ Andreea Gangone PhD \\ “Constantin Brâncoveanu" University, Piteşti, Romania
}

(Received February 2017; Accepted May 2017)

\begin{abstract}
While scholarly literature abounds with research on organizational culture and CSR, this study adds knowledge to the field, redefining a new concept: that of socially responsible organizational culture. In our opinion, socially responsible organizational culture encompasses all the values, beliefs, norms and strategies that facilitate, direct, operate and develop the relations between organization and stakeholders in order to harmonize these relationships and increase economic, social and environmental performance. This paper creates a conceptual model of socially responsible organizational culture and presents a methodology for evaluating socially responsible organizational culture in the EU Member States. Results show significant variations between states, explained by differences in national culture, attitude and focus on CSR actions.

Key words: socially responsible organisational culture (SROC), organisational culture, CSR, stakeholders, economic, social and environmental performance.
\end{abstract}

JEL Codes: M14, M21, D22.

\section{Introduction}

The current global context determines companies to become more aware than in the past of the importance of socially responsible business and of the need to develop a responsible and ethical organizational culture. Moreover, organizational culture and corporate social responsibility are related to competitiveness and competition (Ganescu, 2011), which shows their stronger impact on organizational performance on the medium and long term.

Scholarly literature abounds with research on organizational culture and corporate social responsibility, which are most often approached separately or, at best, in interrelation. In this sense, Swanson (1999) argues that fostering a CSR-supportive, value-driven culture is a key challenge on the journey to CSR, because the presence and progressive growth of a CSR-supportive organizational culture constitutes an essential leverage for the organization's further CSR development. For Doppelt (2003, p.92), "cultures are storehouses of organisational information and knowledge than can assist or thwart sustainability efforts". Berger et al. (2007) 
states that organizational culture shapes the context within which organizations design and operationalize their strategy and policies and exerts considerable influence on the organization's CSR development. Therefore, the existing culture of an organization significantly affects the organization's potential CSR development. Maon, Lindgreen and Swaen (2010, p.25) argue that "a stakeholder culture constitutes a dominant dimension of a CSR-supportive organizational culture" and, therefore, "CSR-related values must become deeply integrated into the management philosophy and organizational culture" (Maon, Lindgreen and Swaen, 2010, p.35).

The concept of socially responsible organizational culture (SROC) is a new concept (Hemingway, 2013), insufficiently explained and studied to date in scholarly literature, and created to highlight the logical relationship between declared values and corporate actions.

Currently, the need to research socially responsible organizational culture grew stronger, as current dynamics of the external environment urge for major changes in companies. In addition, the implementation of corporate social responsibility strategies is becoming a necessity, given that "the objectives of sustainable business have become increasingly more important for companies, but also for stakeholders" (Ganescu, 2012).

This study deals with a relatively new field in scholarly literature and aims to create a conceptual model of socially responsible organizational culture. The second section of the paper defines the concepts of organizational culture (OC) and corporate social responsibility (CSR) in order to identify the scope of this phenomenon at organizational level. The third section defines the concept of socially responsible organizational culture (SROC) and describes the conceptual model of socially responsible organizational culture, while the fourth section presents the methodology for evaluating socially responsible organizational culture in the EU Member States. Finally, the paper presents the research findings.

\section{Organizational culture and corporate social responsibility}

For over three decades, researchers have shown significant interest in explaining the concept of organizational culture. As an organizational phenomenon, organizational culture is difficult to explain, making it hard to obtain consensus among experts on the significance of this concept.

According to Edgar Schein, "culture is the sum total of all the shared, taken-forgranted assumptions that a group has learned throughout its history" (Schein, 1999). Organizational culture characterizes all the members of an organization or most of them, forming a characteristic and dominant pattern that is stable in time. Thus, according to renowned researcher Geert Hofstede, organizational culture is a 
"collective mental programming that distinguishes members of an organization from those of another organization" (Hofstede, 1996, p. 208). According to Samuel Certo, organizational culture includes "a number of common values and beliefs that members of the organization hold regarding the functioning and existence of their organization" (Certo, 2002, p. 520).

As a business philosophy of the organization, organizational culture "should reflect the reasoning of investors and managers, the ethical standards they employ in making decisions, the traditions, attitudes and concrete situations experienced by the organization" (Gangone 2014, p. 85).

As a source of performance, organizational culture includes "all the enterprisespecific values, beliefs, attitudes, which give it identity, are relatively stable and significantly influence the success or failure of the members and of the organization as a whole" (Ganescu 2011, p. 20).

Research conducted over the years has focused on three significant aspects of organizational culture (Linnenluecke and Griffiths, 2010, p. 358): creating the conceptual base and the framework needed to determine the dimensions of organizational culture; measuring and assessing values, ideologies, and beliefs deemed important and reliable; determining the role of organizational culture in reducing or increasing resistance to technological and managerial changes. Failure to implement organizational change is explained by the fact that managers are concerned more with strategies, tools or techniques than with changing the values of an organization.

Within an organization, organizational culture performs the following functions (Adler, 1986, p. 145): integrates and adapts employees to the internal environment; protects employees against potential threats from the external environment; preserves and communicates the values and traditions of the organization; creates an appropriate framework for the development of organizational capacity and provides strategic competitive advantages.

Organizational culture is a key determinant of the ethical behaviour of managers and other employees. The ethical dimension of organizational culture is evident if we consider the organizational culture - competitiveness interrelationship model (Ganescu 2011, pp. 94-95): positive organizational culture includes values, beliefs and behaviour norms transmitted by shareholders and managers and adopted by all employees of an organization, to the extent to which they correspond to expectations; once adopted, these elements translate into expected behaviours and attitudes, both internally and in relation to the external environment; behaviours are formed over time, based on rules of conduct established by codes of conduct, but also based on plans and objectives of the company; ethical behaviour is a prerequisite to obtaining high performance and competitive advantage.

Studia Universitatis "Vasile Goldis" Arad. Economics Series Vol 27 Issue 2/2017

ISSN: 1584-2339; (online) ISSN: $2285-3065$

Web: publicatii.uvvg.ro/index.php/studiaeconomia.Pages 45 - 59 
Authors Jaakson, Vadi and Tamm (2009) identified a set of dimensions that characterized each organizational culture: task orientation and relationship orientation (task orientation, relationship orientation). Task orientation implies acceptance by employees of objectives and tasks, recognizing their role in achieving the general objectives of the organization. Relationship orientation increases individuals' sense of belonging to a group, cohesion, participation and cooperation between members of the organization.

In general, when analysing organizational culture, authors focus on domestic interest holders, such as managers, shareholders or employees. However, engaging in activities that are specific to corporate social responsibility requires the involvement of both internal and external stakeholders, such as shareholders, employees, community, customers and suppliers.

Corporate social responsibility is a concept closely related to business ethics, corporate philanthropy, corporate citizenship, socially responsible investment, sustainability, and organizational culture. As such, "CSR is defined as a concept whereby companies integrate social and environmental concerns in their business operations and in their interaction with their stakeholders on a voluntary basis" (European Commission, 2001).

Based on stakeholder theory,"CSR is the financial or non-financial, direct or indirect degree of empathy shown by an organisation in relation to stakeholders during the organisation's activity. From this perspective, we believe that identifying stakeholders and identifying their commitment to corporate social responsibility are fundamental" (Gangone and Ganescu, 2014).

The complexity of the corporate social responsibility concept justifies identifying its six facets (Gangone, 2014, pp. 31-35): on the one hand, it is a determining factor in shaping social management; on the other hand, it is a firm obligation of the organization in its relationship with society; a voluntary action of the organization; a method and tool for improving social status; an instrument to operationalize the stakeholder theory; a business philosophy and an operational instrument for the concept of sustainable development.

Studies conducted in Romania on corporate social responsibility have shown a growing interest of both researchers and practitioners. For the most part, these studies focused on determining managers' opinion on corporate social responsibility activities (Bibu, Nastase and Gligor, 2010; Obrad et al., 2011) or on the stage of implementation of European standards in Romanian companies (Olaru, Stoleriu and Sandru, 2011). The aforementioned studies have failed to show the inability, impossibility or disinterest of Romanian organizations in implementing corporate social responsibility as part of the organization's strategy. 
In scholarly literature, there are a few attempts to determine the relationship between organizational culture and CSR. Thus, according to Strautmanis (2007), "Social responsibility is part of organizational culture and a value in the corporate environment".

Scholarly literature presents some studies highlighting the link between CSR and organizational culture (Ubius and Alas, 2009), which state that certain types of organizational cultures anticipate certain facets of corporate social responsibility and support improved social performance of the organization or the interests of stakeholders.

From a managerial perspective, developing integrated CSR initiatives becomes possible when managerial views evolve and 'ethical' decision-making receives support from the organizational culture (Trevino and Nelson, 2007). Authors Maignan and Ferrell (2004) demonstrated the role of CSR in marketing and underlined the relevance of organizational rules and culture.

From stakeholder theory perspective, some authors believe that "CSR policies and practices, the treatment of stakeholders and the ability to demonstrate social responsibility are influenced by many variables," including organizational culture (Wood, 1991). Based on the stakeholder culture theory formulated by Jones et al. (2007), Maon, Lindgreen and Swaen (2010, p.26) "contend that there are contingent relationships between the dominant stakeholder culture of an organization and its propensity and ability to respond to social expectations, which in turn dictates the nature and scope of the development of its CSR commitments". These authors present "a practical, comprehensive CSR model which consolidates various perspectives into a robust model with three cultural phases and seven organizational stages", offering new perspectives for the analysis of organizations' CSR development processes (Maon, Lindgreen and Swaen, 2010, p. 34).

Other studies determined the connection between organizational culture and stakeholders' expectations (Hillman and Keim, 2001). Those organizations that apply high ethical standards and show concern for the needs of stakeholders connect their activity to values such as "interdependence, empathy, fairness, personal responsibility, intergenerational justice, cooperation and partnership, communication and dialogue" (Jaakson, Vadi and Tamm, 2009, p. 9).

There is also research that examines the relationship between CSR and national culture, taking into account one of the pair dimensions of national culture in particular: individualism-collectivism. Unfortunately, the effect of collectivism or individualism on CSR is not clearly explained.

Other studies looked at the nature of CSR in relation to corporate reputation, based on the theory of values (Siltaoja, 2006), identifying core values in various cultures. 
Ganescu C., Gangone A. (2017)

A model of socially responsible organizational culture

In an attempt to identify the determinants of CSR, authors Yu and Choi (2016) established that the pressure of stakeholders had a positive impact on Chinese companies carrying out CSR activities. Since previous studies were not relevant in this respect, the authors examined the mediating role of CSR-oriented organizational culture in order to determine the relation between the pressure of stakeholders and CSR. The result of this study showed that Chinese organizations should promote a CSR oriented organizational culture and establish an effective CSR policy to help them achieve competitive advantage.

Similarly, Jaakson, Vadi and Tamm (2009) concluded that organizational performance mediated the relationship between organizational culture and CSR. Organizations with a mature organizational culture correlated with CSR initiatives that benefited stakeholders. On the other hand, CSR transcended organizational culture through groups of employees involved in CSR activities.

The orientation of organizational culture includes two dimensions that are relevant to corporate social responsibility (Cooke and Rousseau, 1988): "direction and intensity". The direction reflects the content of organizational culture, including behavioural norms, values and beliefs. On the other hand, the intensity reflects the strength of the direction of organizational culture. Both dimensions affect how employees think and act in relation to tasks and other people.

The orientation towards the needs of others, specific to humanistic cultures, creates links between employees and other stakeholders, outside the organization. According to Galbreath (2009),"a humanistic culture has a positive effect on CSR, over and above what could be expected on the basis of formal strategic planning".

So far, the concepts of organizational culture and CSR were treated separately or interrelated. This paper formulates and defines a new concept, that of socially responsible organizational culture.

\section{The conceptual model of socially responsible organizational culture}

In our opinion, socially responsible organizational culture encompasses all the values, beliefs, norms and strategies that facilitate, direct, operate and develop the relations between organization and stakeholders in order to harmonize these relationships and increase economic, social and environmental performance.

The conceptual model of socially responsible organizational culture defines in an innovative manner the essential components of socially responsible organizational culture:

- the tangible component (sustainable business model, environmental performance, responsible behaviour towards customers and suppliers, responsible human resources policies, decision-making transparency responsibility to retain talents); 
- the spiritual or intangible component (ethical and responsible values, innovative spirit, spirit of unity and agreement, attitude towards corruption, trust).

The first component, the tangible one, is related to the defining elements of socially responsible corporate culture, elements that are evident to all the stakeholders.

a) the sustainable business model is the core of a business that provides long-term added value to shareholders and other stakeholders and leads to competitive advantage through sustainable global strategies.

The specific elements of the concept of sustainable business model are (Boons and Ludeke-Freund, 2013, pp.10-13):

- "value proposition - what value is embedded in the product/service offered by the firm; reflects a business-society dialog concerning the balance of economic, ecological and social needs as such values are temporally and spatially determined)";

- "supply chain (how are upstream relationships with suppliers structured and managed; the focal company actively engages suppliers into sustainable supply chain management)";

- "customer interface (how are downstream relationships with customer structured and managed; the customer interface motivates customers to take responsibility for their consumption)";

- "financial model - costs and benefits from value proposition, supply chain, customer interface and their distribution across business model stakeholders"; "the financial model reflects an appropriate distribution of economic costs and benefits among actors involved in the business model and accounts for the company's ecological and social impacts" (Maas and Boons, 2010).

Integrating corporate social responsibility and sustainability into the business model leads to increased positive externalities of a company and reduced negative ones.

b) "The environmental performance of the organization is based on the level of pollution emissions released by the firm" (Stanwick and Stanwick, 1998, p.197). This variable highlights the organization's ability to perform responsibly towards the environment.

c) Responsible behaviour towards customers and suppliers is defining for a socially responsible organizational culture as suppliers and customers contribute to the success or failure of a business, affecting the cost, price, quality or image of an organization.

d) Responsible human resources policies are one of the elements of internal environment of an organization and an important factor for success. Thus, a socially responsible organizational culture allows integration, protection and 
Ganescu C., Gangone A. (2017)

A model of socially responsible organizational culture

development of employees, is concerned with the needs of all and contributes to building an inclusive environment.

e) Decision-making transparency is a specific concern of managers interested in creating a socially responsible organizational culture. Ensuring transparency of the decision-making system generates benefits for both the managers and the organization, as it reduces resistance to change, creates trust and increases the feeling of affiliation to the group. In addition, it ensures customer loyalty and supplier support, an indicator of responsible policies and practices of the organization.

f) The responsibility to retain talent is a feature of socially responsible organizational culture with a role in facilitating communication, teamwork, creativity and innovation (Earle, 2003). As a result, the organization can ensure its future development and meet the expectations of all the stakeholders: shareholders, employees and community.

The second component, the spiritual or intangible component, becomes more difficult to identify and analyse as it includes elements of mythical nature: values, attitudes, beliefs, mindsets.

a) Responsible and ethical values are the essence of organizational culture. The value system allows a ranking of situations, actions and ideas, from ethical to unethical. According to Carroll (1991), the ethical responsibility of a company is a part of CSR. Thus, any organization must conduct their business reasonably to meet the demands of society. Organizations wishing to hold a socially responsible organizational culture must adhere to positive attitudes that create socially responsible concern for philanthropy, interest in solving community's problems, find new ways of creating common good.

b) The innovative spirit is specific to strong organizational cultures. Therefore, socially responsible organizational culture must create a climate that is open to creativity and innovation in order to meet both organizational objectives and the needs of all its stakeholders.

c) The spirit of unity and agreement is a feature of socially responsible organizational culture. Thus, the individual identifies with the group to which it belongs and acknowledges the role played by all group members in achieving economic and social performance. All team members must act together and focus on the group's results and the stakeholders' needs.

d) The attitude towards corruption is based on clear rules, specific to socially responsible organizational culture, which guide employees, and reject and penalize corruption manifested at the organizational level. Corruption can benefit individuals, affecting not only the interests of the entire organizations, but also those of other stakeholders. The existence of a code of ethics does not reduce the 
possibility of corruption (Ashforth et al., 2008). Socially responsible organizational culture is one that integrates formal and informal rules into the daily work, reducing deviations from ethics and establishing the belief that one can accomplish one's goals without harming the interests of others.

e) Trust is an attitude that is necessary when developing sustainable and successful business relationships with customers, suppliers, managers, shareholders and institutions. Socially responsible organizational culture builds and develops trust between employees, managers, partners and allows avoiding and resolving conflicts through informal rules.

Creating and developing a socially responsible corporate culture brings long-term benefits to the organization and all the stakeholders. Starting from the idea outlined by Kotter and Heskett (1992) that "organizational culture influences organizational performance when it helps the organization to anticipate or adapt to changes in the environment," we believe that organizations that are able to strengthen their socially responsible organizational culture will substantially contribute not only to increasing the sustainability of their businesses, but also to creating a sustainable business.

\section{Assessing socially responsible organizational culture in EU Member States, based on a proprietary methodology}

The aim of this study is to evaluate socially responsible corporate culture by building a methodology to calculate the index of socially responsible organizational culture $\left(\mathrm{I}_{\mathrm{SROC}}\right)$ and a ranking of EU member states, based on the results. The reason for choosing European Union member countries is the cultural, social and economic diversity in these states. In addition, we believe it is important that European Union organizations realize the importance of socially responsible organizational culture in increasing economic, social and environmental performance.

The methodology for determining $\mathrm{I}_{\mathrm{SROC}}$ for 2016 involved the content analysis of Eurostat databases (European Commission, 2016), the 2016-2017 Global Competitiveness Report issued by the World Economic Forum (Schwab, 2016), the 2016 Global Innovation Index (Dutta, Lanvin and Wunsch-Vincent, 2016), the 2016 Transparency Internationals Corruption Perceptions Index - CPI (Transparency International, 2016), the Environmental Performance Index (Hsu, 2016) and of the value of dimensions of the national cultural system determined by Geert Hofstede (Hofstede, Hofstede and Minkov, 2010). 
Ganescu C., Gangone A. (2017)

A model of socially responsible organizational culture

Table no. 1. Measurement variables of $I_{S R O C}$ and specific assessment indicators of socially responsible organizational culture

\begin{tabular}{|c|c|c|c|c|}
\hline Subindex & Variable & Indicators & $\begin{array}{c}\text { Code of } \\
\text { indicators }\end{array}$ & Source \\
\hline \multirow{6}{*}{$\begin{array}{l}\text { Tangible } \\
\text { component } \\
\text { subindex }\end{array}$} & $\begin{array}{l}\text { The sustainable } \\
\text { business model }\end{array}$ & $\begin{array}{l}\text { Business } \\
\text { sophistication }\end{array}$ & $\mathrm{BS}$ & $\begin{array}{l}\text { Schwab, } 2016 \text { - } \\
\text { GCR }\end{array}$ \\
\hline & $\begin{array}{l}\text { Environmental } \\
\text { performance }\end{array}$ & EPI & EPI & Hsu, 2016 - EPI \\
\hline & $\begin{array}{l}\text { Responsible } \\
\text { behaviour towards } \\
\text { customers and } \\
\text { suppliers }\end{array}$ & $\begin{array}{l}\text { Integration with } \\
\text { customers/suppliers, } \\
\text { supply chain } \\
\text { management }\end{array}$ & ICSCM & $\begin{array}{l}\text { European } \\
\text { Commission, } \\
2016 \text { - Eurostat }\end{array}$ \\
\hline & $\begin{array}{l}\text { Responsible human } \\
\text { resources policies }\end{array}$ & $\begin{array}{l}\text { Cooperation in labor- } \\
\text { employer relations }\end{array}$ & CLR & $\begin{array}{l}\text { Schwab, } 2016 \text { - } \\
\text { GCR }\end{array}$ \\
\hline & $\begin{array}{l}\text { Decision-making } \\
\text { transparency }\end{array}$ & $\begin{array}{l}\text { Hiring and firing } \\
\text { practices }\end{array}$ & HFP & $\begin{array}{l}\text { Schwab, } 2016 \text { - } \\
\text { GCR }\end{array}$ \\
\hline & $\begin{array}{l}\text { The responsibility to } \\
\text { retain talent }\end{array}$ & $\begin{array}{l}\text { Country capacity to } \\
\text { retain talent }\end{array}$ & CCRT & $\begin{array}{l}\text { Schwab, } 2016 \text { - } \\
\text { GCR }\end{array}$ \\
\hline \multirow{5}{*}{$\begin{array}{l}\text { The } \\
\text { intangible or } \\
\text { spiritual } \\
\text { component } \\
\text { subindex }\end{array}$} & $\begin{array}{l}\text { Responsible and } \\
\text { ethical values }\end{array}$ & $\begin{array}{l}\text { Ethical behaviour of } \\
\text { firms }\end{array}$ & EBF & $\begin{array}{l}\text { Schwab, } 2016 \text { - } \\
\text { GCR }\end{array}$ \\
\hline & The innovative spirit & GII & GII & $\begin{array}{l}\text { Global } \\
\text { Innovation Index, } \\
2016 \\
\end{array}$ \\
\hline & $\begin{array}{l}\text { The spirit of unity } \\
\text { and agreement }\end{array}$ & $\begin{array}{l}\text { Hofstede, } \\
\text { individualism - } \\
\text { collectivism } \\
\end{array}$ & $\mathrm{HO}$ & $\begin{array}{l}\text { Hofstede, } \\
\text { Hofstede and } \\
\text { Minkov, } 2010\end{array}$ \\
\hline & $\begin{array}{l}\text { The attitude towards } \\
\text { corruption }\end{array}$ & $\begin{array}{l}\text { Corruption } \\
\text { Perceptions Index - } \\
\text { CPI } 2016\end{array}$ & CPI & $\begin{array}{l}\text { Transparency } \\
\text { Internationals, } \\
2016 \text { - CPI } 2016 \\
\end{array}$ \\
\hline & Trust & $\begin{array}{l}\text { Level of citizens' } \\
\text { confidence in EU } \\
\text { institutions }\end{array}$ & $\mathrm{LCC}$ & $\begin{array}{l}\text { European } \\
\text { Commission, } \\
2016 \text { - Eurostat }\end{array}$ \\
\hline
\end{tabular}

Source: author's view

The steps in building $\mathrm{I}_{\mathrm{SROC}}$ were: create a list of EU Member States; build and populate the database necessary for research by entering the values identified for each specific assessment indicator of socially responsible organizational culture (Tab. no. 1).

The lack of data needed to assess the spirit of unity and agreement for Cyprus imposed the exclusion of this state from the list. The values of quantitative and qualitative indicators have been aggregated and transformed using the min-max method, to maintain order and relative distance between the scores of various analysed countries. We applied a weighting coefficient of 0.50 to each subindex. In 
computing the value of $\mathrm{I}_{\mathrm{SROC}}$, we calculated the average of the two subindexes, using the following formula:

$I_{S R O C}=\left(I_{1}+I_{2}\right) / 2$

where: $\mathrm{I}_{S R O C}-$ the value of socially responsible organizational culture; $\mathrm{I}_{1}, \mathrm{I}_{2}$ - subindexes that characterize each component.

For subindexes $I_{1}$ and $I_{2}$, we calculated the average of the values of the indicators that compose them:

$\mathrm{I}_{1}=(\mathrm{BS}+\mathrm{EPI}+\mathrm{ICSCM}+\mathrm{CLR}+\mathrm{HFP}+\mathrm{CCRT}) / 6$

$\mathrm{I}_{2}=(\mathrm{EBF}+\mathrm{GII}+\mathrm{HO}+\mathrm{CPI}+\mathrm{LCC}) / 5$

Table no. 2. A ranking of EU Member States based on the value of the socially responsible organizational culture index (excluding Cyprus), for 2016

\begin{tabular}{|c|c|c|c|c|}
\hline No. & Country & $\begin{array}{l}\text { The tangible } \\
\text { component } \\
\text { subindex }\left(I_{1}\right)\end{array}$ & $\begin{array}{c}\text { The intangible or } \\
\text { spiritual component } \\
\text { subindex }\left(I_{2}\right)\end{array}$ & $\mathbf{I}_{\text {SROC }}$ \\
\hline 1. & Denmark & 4.725 & 3.693 & 4.209 \\
\hline 2. & Sweden & 3.817 & 3.839 & 3.828 \\
\hline 3. & Finland & 4.103 & 3.267 & 3.685 \\
\hline 4. & United Kingdom & 3.347 & 3.563 & 3.455 \\
\hline 5. & The Netherlands & 2.966 & 3.524 & 3.245 \\
\hline 6. & Ireland & 3.119 & 3.075 & 3.097 \\
\hline 7. & Luxembourg & 2.931 & 3.144 & 3.037 \\
\hline 8. & Germany & 2.879 & 3.039 & 2.959 \\
\hline 9. & Austria & 2.972 & 2.624 & 2.798 \\
\hline 10. & Estonia & 2.844 & 2.387 & 2.615 \\
\hline 11. & Belgium & 1.874 & 2.962 & 2.418 \\
\hline 12. & France & 1.978 & 2.623 & 2.301 \\
\hline 13. & Malta & 2.313 & 1.932 & 2.123 \\
\hline 14. & Spain & 2.163 & 1.504 & 1.834 \\
\hline 15 . & Latvia & 1.896 & 1.745 & 1.821 \\
\hline 16. & Lithuania & 1.787 & 1.709 & 1.748 \\
\hline 17. & Slovenia & 2.302 & 1.156 & 1.729 \\
\hline 18. & Czech Republic & 1.811 & 1.640 & 1.726 \\
\hline 19. & Portugal & 2.080 & 1.294 & 1.687 \\
\hline 20. & Italy & 1.586 & 1.491 & 1.538 \\
\hline 21. & Hungary & 1.467 & 1.410 & 1.439 \\
\hline 22. & Poland & 1.092 & 1.577 & 1.335 \\
\hline 23. & Slovakia & 1.289 & 1.080 & 1.185 \\
\hline
\end{tabular}

DE GRUYTER OPEN
Studia Universitatis "Vasile Goldis" Arad. Economics Series Vol 27 Issue 2/2017 ISSN: 1584-2339; (online) ISSN: 2285 - 3065 
Ganescu C., Gangone A. (2017)

A model of socially responsible organizational culture

\begin{tabular}{|c|l|l|l|l|}
\hline 24. & Bulgaria & 1.286 & 0.603 & 0.944 \\
\hline 25. & Greece & 1.179 & 0.589 & 0.884 \\
\hline 26. & Romania & 0.960 & 0.575 & 0.767 \\
\hline 27. & Croatia & 0.878 & 0.651 & 0.765 \\
\hline
\end{tabular}

Source: author's view

The ranking highlights the position of each EU Member State according to the value of the index of socially responsible organizational culture (Tab. no. 2). Higher values of the index for the first countries in the ranking (Denmark, Sweden, Finland, UK, The Netherlands) show the concern of organizations operating in these countries to create and develop a socially responsible organizational culture that is characterized by responsible values, attitudes and behaviours aimed at meeting the expectations of all the stakeholders and increasing economic, social and environmental performance. Member in the upper positions of the ranking are countries with developed economies where companies own and employ CSR policies. Bulgaria, Greece, Romania and Croatia took the last positions in the ranking, as they obtained low values of the index of socially responsible organizational culture. In these countries, there is little interest in promoting and strengthening responsible values. Romania recorded the lowest values of indices measuring responsibility to retain talents and innovative spirit, explaining the migration of highly skilled people to other economically attractive Member States. Surprisingly, the value of the index measuring trust in institutions is close to maximum for Romania, compared to Britain, which has the lowest value.

We believe that rethinking European organizations' personalities, values systems, beliefs, behaviours and norms, and creating socially responsible organizational culture are dignified solutions for organizations that want economic, social and environmental performance.

The results of this study can be used in future researches, such as comparative analyses between the states, and provide the premises for interesting correlations between $\mathrm{I}_{\mathrm{SROC}}$ and national performance in terms of competitiveness, innovation, sustainable development, international migration etc.

The index of socially responsible organizational culture whose measurement methodology has been described in this research can be calculated only for EU countries, as it comprises variable calculated, so far, only in this space.

\section{Conclusions}

Given that scholarly research abounds in research on organizational culture and CSR, this study adds knowledge to the field by redefining a new concept, that of socially responsible organizational culture. The paper also creates a model to assess 
socially responsible organizational culture, allowing a ranking of EU states. Results show significant differences between states, explained by differences in national culture, attitudes and focus on CSR actions.

The present study has some limitations, which derive from the qualitative nature of the variables used in determining the index and the lack of data for some measurement variables, necessary for such a panel-type evaluation. However, this study enables evaluation and comparison of socially responsible organizational culture through a national index. The methodology can be improved by increasing its complexity and by adding other measurement variables.

\section{References}

1. Adler, N., 1986. International Dimensions of Organizational Behaviour. Boston: McGraw Hill.

2. Ashforth, B.E., Gioia, D.A., Robinson, S.L. and Trevino, L.K., 2008. Introduction to special topic forum re-viewing organizational corruption. Academic of Management Review, 33(3), pp.670-684.

3. Berger, I.E., Cunningham, P. and Drumwright, M.E., 2007. Mainstreaming corporate social responsibility: developing markets for virtue. California Management Review,

4. 49, pp.132-157.

5. Bibu, N., Nastase, M. and Gligor, D.C., 2010. The perception over Corporate Social Responsibility in Romania. Review of International Comparative Management, 11(5), pp.764-778.

6. Boons, F. and Ludeke-Freund, F., 2013. Business models for sustainable innovation: state-of-theart steps towards a research agenda. Journal of Cleaning Production, 45, pp.p-19.

7. Carroll, A., 1991. The Pyramid of Corporate Social Responsibility: Toward the Moral Management of Organizational Stakeholders. Business Horizons, 34, pp.39-48.

8. Certo, S., 2002. Managementul modern. BucureSti: Teora Publishing House.

9. Cooke, R.A. and Rousseau, D.M., 1988. Behavioural norms and expectations: a quantitative approach to the assessment of organizational culture. Group Organization Studies, 13, pp.245-273.

10. Doppelt, B., 2003. Leading Change Toward Sustainability. Sheffield: Greenleaf Publishing.

11. Dutta, S., Lanvin, B. and Wunsch-Vincent, S., 2016. The Global Innovation Index 2016: Winning with Global Innovation. Available at: https://www.globalinnovationindex. org/gii-2016-report. Accesed 9 January 2017.

12. Earle, H.A., 2003. Building a workplace of choice: Using the work environment to attract and retain top talent. Journal of Facilities Management, 2(3), pp.244-257.

13. European Commission, 2001. Promoting a European Framework for Corporate Social Responsibility: Green Paper. Brussels.

14. Galbreath, J., 2009. Drivers of Corporate Social Responsibility: The Role of Formal Strategic Planning and Firm Culture. British Journal of Management, 21, pp.511-525.

Studia Universitatis "Vasile Goldis" Arad. Economics Series Vol 27 Issue 2/2017

ISSN: 1584-2339; (online) ISSN: 2285 - 3065

Web: publicatii.uvvg.ro/index.php/studiaeconomia.Pages $45-59$ 
15. Gangone, A.D., 2014. Responsabilitate sociala corporatista. Repere conceptuale. Abordari strategice. Particularitaţi culturale. BucureSti: Universitara Publishing House.

16. Gangone, A.D. and Ganescu, M.C., 2014. Corporate social responsibility in emerging and developing economies in Central and Eastern Europe - a measurement model from the stakeholder theory perspective. Economic Research-Ekonomska Istraživanja, 27(1), pp.539-558.

17. Ganescu, C., 2012. Corporate social responsibility, a strategy to create and consolidate sustainable businesses. Theoretical and Applied Economics, 19(11), pp.91-106.

18. Ganescu, C., 2011. Cultura organizaţionala Si competitivitatea. BucureSti: Universitara Publishing House.

19. Hemingway, C.A., 2013. Corporate Social Entrepreneurship. Integrity Within. Cambridge: Cambridge University Press.

20. Hillman, A. and Keim, G., 2001. Shareholder value, stakeholder management, and social issues: what's the bottom line? Strategic Management Journal, 22(2), pp.125-139.

21. Hofstede, G., Hofstede, G.J. and Minkov, M., 2010. Cultures and Organizations: Software of the Mind. Revised and Expanded 3rd Edition. New York: McGraw-Hill USA.

22. Hofstede, G., 1996. Managementul structurilor multiculturale. Software-ul gândirii. BucureSti: Economica Publishing House.

23. Hsu, A., 2016. 2016 Environmental Performance Index. New Haven: Yale University. [on-line] Available at: <www.epi.yale.edu > [Accesed 15 January 2017].

24. Jaakson, K., Vadi, M. and Tamm, K., 2009. Organizational culture and CSR: an exploratory study of Estonian servce organizations. Social Responsibility Journal, 5(1), pp.6-18.

25. Jones, T.M., Felps, W. and Bigley, G., 2007. Ethical theory and stakeholder-related decisions: The role of stakeholder culture. Academy of Management Review, 32, pp.137-155.

26. Kotter, J.P. and Heskett, J.L., 1992. Corporate culture and performance. New York: Free Press.

27. KPMG International, 2016. 2016 Change Readiness Index. Oxford: Oxford Economics.

28. Linnenluecke, M.K. and Griffiths, A., 2010. Corporate sustainability and organizational culture. Journal of World Business, 45, pp.357-366.

29. Maas, K.E.H., Boons, F.A.A., 2010. CSR as a strategic activity: value creation, redistribution and integration. In: Louche, C., Idowu, S., Leal Filho, W. (Eds.), Innovative CSR: From Risk Management to Value Creation. Greenleaf, London, pp. 154-172.

30. Maignan, I. and Ferrell, O.C., 2004. Corporate social responsibility and marketing: an integrative framework. Journal of the Academy of Marketing Science, 32(1), pp.3-19.

31. Maon, F., Lindgreen, A. and Swaen, V., 2010. Organizational Stages and Cultural Phases: A Critical Review and a Consolidative Model of Corporate Social Responsibility Development. International Journal of Management Reviews, 12(1), pp.20-38. 
32. Obrad, C., Petcu, D., GhergheS, V. and Suciu, S., 2011. Responsabilitatea sociala a companiilor din România între percepţii Si realitate. Amfiteatru Economic, XIII(29), pp.44-56.

33. Olaru. M., Stoleriu. G. and Sandru, I.M.D., 2011. Preocupari ale IMM-urilor din România privind responsabilitatea sociala în raport cu criteriile modelului european de excelenţa EFQM. Amfiteatru Economic, XIII (29), pp.57-72.

34. Schein, E.H., 1999. Process consultation revisited: Building the helping relationship. Reading, MA: Addison-Wesley.

35. Schwab, K., 2016. The Global Competitiveness Report 2016-2017. Full Data Edition, [Pdf] Available at: http://www3.weforum.org/docs/GCR2016-2017/05FullReport /TheGlobalCompetitivenessReport2016-2017_FINAL.pdf. Accesed 10 January 2017.

36. Siltaoja, M.E., 2006. Value priorities as combining core factors between CSR and reputation - a qualitative study. Journal of Business Ethics, 68(1), pp.91-111.

37. Stanwick, P.A. and Stanwick, S.D., 1998. The Relationship between Corporate Social Performance and Organizational Size, Financial Performance and Environmental Performance: An Empirical Examination. Journal of Business Ethics, 17(2), pp.195-204.

38. Strautmanis, J., 2007. Acquiring Corporate Social Responsibility Approach Through Business Study Process. Riga: University of Latvia.

39. Swanson, D.L., 1999. Toward an integrative theory of business and society: a research strategy for corporate social performance. Academy of Management Review, 24, pp.506-521.

40. Transparency International, 2016. Corruption Perceptions Index 2016 Available at: http://www.transparency.org/news/feature/corruption_perceptions_index_2016.

41. Trevino, L. and Nelson, K., 2007. Managing Business Ethics: Straight Talk About How to Do It Right, 4th edn. New York: Wiley.

42. Ubius, U. and Alas, R., 2009. Organizational Culture Types as Predictors of Corporate Social Responsibility. Engineering Economics, 1(61), pp.90-99.

43. Wood. D.J., 1991. Corporate social performance revisited. Academy of Management Review, 16, pp.691-718.

44. Yu, Y. and Choi, Y., 2016. Stakeholder pressure and CSR adoption: the mediating role of organizational culture for Chinese companies. The Social Science Journal, 53(2), pp.226-235. 